\title{
Durability of Sustainable Ceramics Produced by Alkaline Activation of Clay Brick Residue
}

\author{
Fabiana Pereira da Costa ${ }^{1}{ }^{(}$, Izabelle Marie Trindade Bezerra ${ }^{1}$, Jucielle Veras Fernandes ${ }^{1}(\mathbb{D}$, \\ Alisson Mendes Rodrigues ${ }^{1,2, * \mathbb{C}}$, Romualdo Rodrigues Menezes ${ }^{1,2}$ (i) and Gelmires de Araújo Neves ${ }^{1,2}$ (1) \\ 1 Graduate Program in Materials Science and Engineering (PPG-CEMat), \\ Federal University of Campina Grande, Campina Grande 58429-900, Brazil; \\ fabiana.costa@estudante.ufcg.edu.br (F.P.d.C.); izabelle_marie@yahoo.com.br (I.M.T.B.); \\ jucielle_fernandes@hotmail.com (J.V.F.); romualdo.menezes@ufcg.edu.br (R.R.M.); \\ gelmires.neves@ufcg.edu.br (G.d.A.N.) \\ 2 Laboratory of Materials Technology (LTM), Department of Materials Engineering, \\ Federal University of Campina Grande (UFCG), Campina Grande 58429-900, Brazil \\ * Correspondence: alisson.mendes@professor.ufcg.edu.br
}

check for updates

Citation: Costa, F.P.d.; Bezerra I.M.T.; Fernandes, J.V.; Rodrigues, A.M.; Menezes, R.R.; Neves, G.d.A. Durability of Sustainable Ceramics Produced by Alkaline Activation of Clay Brick Residue. Sustainability 2021, 13, 10931. https://doi.org/ $10.3390 /$ su131910931

Academic Editor: Grigorios

L. Kyriakopoulos

Received: 9 August 2021

Accepted: 6 September 2021

Published: 1 October 2021

Publisher's Note: MDPI stays neutral with regard to jurisdictional claims in published maps and institutional affiliations.

Copyright: (C) 2021 by the authors Licensee MDPI, Basel, Switzerland. This article is an open access article distributed under the terms and conditions of the Creative Commons Attribution (CC BY) license (https:/ / creativecommons.org/licenses/by/ $4.0 /)$.

\begin{abstract}
Alkali-activated materials (AAMs) were produced using residues from the red ceramic industry as a precursor, and sodium hydroxide $(\mathrm{NaOH})$, potassium hydroxide $(\mathrm{KOH})$, and sodium silicate $\left(\mathrm{Na}_{2} \mathrm{SiO}_{3}\right)$ as alkaline activators. The effect of activators and curing conditions on physicalmechanical properties and durability were evaluated. The processing parameters (amount of water and consistency index) and the activation conditions (the activator contents and curing temperature) were defined based on an experimental design getting the flexural rupture module as the response. The durability behavior was evaluated by natural aging, accelerated aging (simulated rain test), exposure to the marine environment (salt fog), and acidic environments $\left(\mathrm{HCl}\right.$ and $\left.\mathrm{H}_{2} \mathrm{SO}_{4}\right)$. The results showed that the $\mathrm{NaOH}$ - and $\mathrm{KOH}$-activated samples exhibited inferior mechanical behavior than those activated with $\mathrm{Na}_{2} \mathrm{SiO}_{3}$. In the durability studies, due to leaching, there was a decrease in mechanical strength when samples are subjected to aggressive exposure conditions. However, the strength values are still higher than the minimum indicated for traditional ceramic applications.
\end{abstract}

Keywords: ceramic residue; alkaline activation; experimental design; durability tests

\section{Introduction}

The red ceramic industry is an important economic segment of the global production chain and generates several jobs. However, vast amounts of residues generate from such industry [1]. Generally, the red ceramic residues generated before the sintering step are reintroduced to the production process, but the residues generated after the sintering step are often discarded in inappropriate places causing damage to the environment. In the past decades, the environmental awareness of society has grown, and several studies have focused on developing new materials from the reuse of industrial waste to contribute to sustainable development [2-6].

The residues of the red ceramic industry have several potentials for reuse; among them stand out the production of traditional ceramics or cementitious materials [7-10]. Additionally, such residues have the potential to be used as precursors of alkali-activated materials because they are rich in silica and alumina and compounds by a large number of amorphous phases [11]. In recent decades, alkali-activated materials (AAMs) have attracted worldwide attention for their low $\mathrm{CO}_{2}$ emissions and excellent mechanical and durability properties. These materials are formed from reactive aluminosilicate raw materials that, in an alkaline medium, undergo a series of chemical reactions giving rise to alkaline aluminosilicate gels with cementitious properties [12].

Due to environmental and technological advantages, AAMs have been widely used in the civil construction sector as an alternative to the use of Portland cement [13], as 
complementary materials to avoid the alkali-aggregate reaction [14] or in the production of ceramic parts without the sintering step [15]. Among the main properties, we can mention high mechanical resistance, more excellent chemical stability, slight curing retraction, greater thermal resistance, more outstanding durability in aggressive environments, and lower $\mathrm{CO}_{2}$ emissions for its production than Portland cement, which is one of the most $\mathrm{CO}_{2}$ emitting in the world [16,17].

Sodium silicate or alkali metal hydroxide ( $\mathrm{Na}$ or $\mathrm{K}$ ) are frequently used activators to produce alkali-activated materials [18]. The most commonly used precursors are materials that have good pozzolanic activity when mixed with Portland cement, such as fly ash [19], blast furnace slag [20], and calcined clays [21]. Additionally, several by-products and industrial wastes have been used as precursor material [22], such as red mud from the bauxite beneficiation process [23], rice husk ashes [24], glass waste [25,26], wastes from ceramic production [18,27-29], among others.

Rego et al. [30] studied various industrial residues, including ceramic residues as a precursor material in synthesizing geopolymer cementitious matrices using hydroxide and silicate activators. The authors observed that the geopolymers produced could be used as adhesives on metal plates subjected to temperatures up to $400{ }^{\circ} \mathrm{C}$, showing better efficiency when compared to epoxy-based resins (adhesion resistance up to $200^{\circ} \mathrm{C}$ ). Azevedo et al. [31] characterized clay brick residues and evaluated their use as an alternative precursor for producing ceramic tiles through geopolymer reactions. The results showed that the ceramic residues showed high pozzolanic reactivity and are rich in silica and alumina, which are fundamental for synthesizing AAMs. Regarding technological analysis, the authors found that the water content and the curing temperature are decisive for improving the mechanical and durability properties of the AAMs.

Although the use of red ceramics residues as a precursor in the production of AAMs has already been reported in the literature, these are still little explored, especially concerning the aspects of durability in aggressive environments, such as seawater and acid exposure. In this sense, this work aimed to produce ceramic pieces through the process of alkaline activation using residues from the red ceramic industry and to evaluate the durability of the pieces formed from tests of natural aging, accelerated aging, and exposure to the marine and acidic environments (hydrochloric acid $(\mathrm{HCl})$ and sulfuric acid $\left(\mathrm{H}_{2} \mathrm{SO}_{4}\right)$ ). For this, three different alkaline agents $\left(\mathrm{NaOH}, \mathrm{KOH}\right.$, and $\left.\mathrm{Na}_{2} \mathrm{SiO}_{3}\right)$ were used as activators. The effect of activators and curing conditions on physical-mechanical properties and durability were evaluated.

\section{Materials and Methods}

\subsection{Materials}

Red ceramic residues (RCR) used in this work came from a commercial brick plant located in the state of Paraíba, Brazil. The residues were ground and sieved for different sizes $0.42 \mathrm{~mm}, 0.18 \mathrm{~mm}$, and $0.074 \mathrm{~mm}$. The alkaline solutions were obtained from sodium hydroxide (PA 97\%, Synth, Diadema-SP, Brazil), potassium hydroxide (PA 85\%, Synth, Diadema-SP, Brazil), and sodium silicate $\left(\mathrm{Na}_{2} \mathrm{O}\right.$ and $\mathrm{SiO}_{2}=20-30 \%, \mathrm{H}_{2} \mathrm{O}=40-60 \%$, VETEC, Duque de Caxias-RJ, Brazil) with basic pH (11-13). Ammonium polyacrylate was used as a dispersant (0.5 wt.\% Lioperses 511, Miracema-Nuodex Indústria Química Ltd.a, CampinasSP, Brazil), and ammonium hydroxide (30-32\% PA, VETEC, Duque de Caxias-RJ, Brazil) was used to adjust the $\mathrm{pH}$.

\subsection{Formulation of the Granulometric Compositions}

The samples were obtained from a combination of three granulometry: \#40 $(0.18 \mathrm{~mm}<$ particles size $\leq 0.42 \mathrm{~mm}), \# 80(0.074 \mathrm{~mm}<$ particles size $\leq 0.18 \mathrm{~mm})$, \#200 (particles size $\leq 0.074 \mathrm{~mm}$ ). Initially, the amount of water needed to obtain a consistency index of $260 \pm 5 \mathrm{~mm}$ [32] was determined using the centroid simplex-type mixture design methodology, augmented with internal points [33]. Two replicates were performed for 
each point (three measurements). Table 1 presents the formulations corresponding to the points defined in the experimental design.

Table 1. Formulations of the granulometric compositions, obtained from the experimental design.

\begin{tabular}{cccc}
\hline \multirow{2}{*}{ Formulations } & \multicolumn{3}{c}{ Fractions $\mathbf{( \% )}$} \\
\cline { 2 - 4 } & $\mathbf{\# 4 0}$ & $\mathbf{\# 8 0}$ & $\mathbf{\# 2 0 0}$ \\
\hline C1 & 100 & 0 & 0 \\
C2 & 0 & 100 & 0 \\
C3 & 0 & 0 & 100 \\
C4 & 50 & 50 & 0 \\
C5 & 50 & 0 & 50 \\
C6 & 0 & 50 & 50 \\
C7 & 33.33 & 33.33 & 33.33 \\
C8 & 68 & 16 & 16 \\
C9 & 16 & 68 & 16 \\
C10 & 16 & 16 & 68 \\
\hline
\end{tabular}

Since the minimum amount of water to reach the consistency index of $260 \pm 5 \mathrm{~mm}$ was determined, another experimental design was accomplished to determine the consistency index. Such analysis was performed using the same data shown in Table 1. Dispersing and $\mathrm{pH}$ control additives were used to obtain the formulations. The significance and prediction of the models were evaluated based on statistical analyses. Due to better workability, composition with the highest consistency index was chosen for alkaline activation studies [34].

\subsection{Characterization of the Red Ceramic Residue and Activated Samples}

The chemical composition was defined by X-ray fluorescence (Shimadzu, EDX 720). The mineralogical phases were identified using the X-ray diffraction technique (Shimadzu, $\mathrm{XRD6000)}$, with $\mathrm{Cu}-\mathrm{K} \alpha 2 \theta$ radiation in the range of angles of $5^{\circ}-70^{\circ}, 0.02^{\circ}$ step and JCPDS database.

\subsection{Alkaline Activation, Curing Times, and Preparation of the Samples}

An experimental design of the $2 \times 2$ factorial type, augmented with star points and a central point was carried out for each activator $\left(\mathrm{NaOH}, \mathrm{KOH}, \mathrm{Na}_{2} \mathrm{SiO}_{3}\right)$ considering the variables of cure temperature and activated concentration. Table 2 presents the experimental design used. The temperatures used in such analysis were based on the works of Rovnaník [35], Medri et al. [36], Bakri et al. [37], and Heah et al. [38]. For calculations of the alkaline activator's concentration, it was considered that all silica is reactive and originated from the kaolinite of the precursor material. The calculations were determined from the chemical composition of the red ceramic residue.

Table 2. Curing temperatures and activator alkaline activator's concentration obtained from experimental design.

\begin{tabular}{ccccc}
\hline \multirow{2}{*}{ Conditions } & Temperature $\left({ }^{\circ} \mathbf{C}\right)$ & \multicolumn{3}{c}{ Concentration $\mathbf{( g / 1 0 0 ~ g ) ~}$} \\
\cline { 3 - 5 } & & $\mathbf{N a O H}$ & $\mathbf{K O H}$ & $\mathbf{N a}_{\mathbf{2}} \mathbf{S O}_{\mathbf{3}}$ \\
\hline 1 & 21.8 & 9.0 & 14.0 & 30.0 \\
2 & 30 & 6.0 & 9.0 & 20.0 \\
3 & 30 & 12.0 & 19.0 & 40.0 \\
4 & 50 & 4.77 & 6.93 & 16.0 \\
5 & 50 & 9.0 & 14.0 & 30.0 \\
6 & 50 & 13.23 & 21.07 & 44.1 \\
7 & 70 & 6.0 & 9.0 & 20.0 \\
8 & 70 & 12.0 & 19.0 & 40.0 \\
9 & 78.2 & 9.0 & 14.0 & 30.0 \\
\hline
\end{tabular}


The mixtures of the red ceramic residue (precursor) with the solutions of each alkaline activator $\left(\mathrm{NaOH}, \mathrm{KOH}\right.$, and $\left.\mathrm{Na}_{2} \mathrm{SiO}_{3}\right)$ were homogenized in a mechanical mixer for $5 \mathrm{~min}$. After that, the homogenous mixture was poured into cylindrical molds with $2.5 \mathrm{~cm} \times 5 \mathrm{~cm}$ (diameter $x$ height) and curing was carried out under temperatures defined in the experimental design (Table 2). The experimental conditions of curing used were 3 days (3d), 5 days ( $5 \mathrm{~d})$, and pre-curing for 4 days in the environment $(\mathrm{E})$, followed by curing under the conditions of the experimental design for 1 day $\left(4 d^{E}+1 d\right)$. The cures at $3 d$ and $4 d^{E}+1 d$ for $\mathrm{Na}_{2} \mathrm{SiO}_{3}$ samples were not performed due to difficulties in demolding the samples.

\subsection{Durability of Samples after Alkaline Activation}

Four tests were accomplished to investigate the durability behavior: natural aging, accelerated aging, exposure to the marine environment (salt fog), and acidic environments $\left(\mathrm{HCl}\right.$ and $\left.\mathrm{H}_{2} \mathrm{SO}_{4}\right)$. For the natural aging test, the samples were kept in a closed place and protected from climatic variations in which the temperature variation $\left(\sim 22{ }^{\circ} \mathrm{C}-33^{\circ} \mathrm{C}\right)$ and the air humidity $(\sim 75 \%)$ were kept constant. The samples were evaluated at 28,60 , and 90 days. The accelerated aging test was carried out through a simulated rain test, with $2 \mathrm{~h}$ wetting cycles and drying for $48 \mathrm{~h}$ in an oven (temperature $35^{\circ} \mathrm{C}$ ). Twenty-four cycles were performed.

Regarding the marine environment test, the samples were exposed in a coastal area, $100 \mathrm{~m}$ from the coastline for 28,60, and 90 days to salt spray. For the acid resistance test, the samples were immersed in solutions (5\% concentration) of hydrochloric acid $(\mathrm{HCl})$ and sulfuric acid $\left(\mathrm{H}_{2} \mathrm{SO}_{4}\right)$ for 28,60 , and 90 days. Then the samples were dried in an oven $\left(35^{\circ} \mathrm{C}\right)$ for $48 \mathrm{~h}$. After the curing and durability tests, three points flexural strength (FS) tests were performed. Such experiments were accomplished in Shimadzu, AG-X-50 KN, with a speed of $0.5 \mathrm{~mm} \cdot \mathrm{min}^{-1}$. The experimental values showed in this work correspond to the average value of ten samples.

\section{Results and Discussion}

\subsection{Amount of Water and Consistency Index}

Figure $1 \mathrm{a}, \mathrm{b}$ shows $3 \mathrm{D}$ response surface plots, obtained from the cubic regression model, for amount of water and consistency index versus RCR formulations with different granulometric fractions: \#40 (0.18 $\mathrm{mm}<$ particles size $\leq 0.42 \mathrm{~mm})$, \#80 (0.074 $\mathrm{mm}<$ particles size $\leq 0.18 \mathrm{~mm}$ ), \#200 (particles size $\leq 0.074 \mathrm{~mm}$ ). Statistical treatment of the experimental data was performed to verify the significance and prediction of the experimental design. The cubic regression model was the most appropriate (95\% confidence) to represent the amount of minimum water and the consistency index. Total of $320 \mathrm{~mL}$ was the minimum amount of water to obtain a consistency index of $260 \pm 5 \mathrm{~mm}$. Such value was observed in the region highlighted in Figure 1a (red hyperbole). This was because the RCR formulations contained in these regions probably favored better particle packing. Then, for the consistency index evaluation, the amount of water was kept constant at $320 \mathrm{~mL}$. The part highlighted in Figure 1b (blue hyperbole) presents values of consistency index ranging from 240 to $280 \mathrm{~mm}$, close to the value of $260 \pm 5 \mathrm{~mm}$ recommended by the ASTM C1437 standard [32]. RCR formulations contained in this region have higher amounts of \#80 and \#200 fractions.

According to the results of the experimental design carried out for the amount of water and the consistency index, the Z composition (40\% of \#40, 2.5\% of \#80, and 57.5 of \#200) was chosen to evaluate under which cure temperatures and alkaline activators concentrations obtained the best flexural strength values. 


\section{(a)}
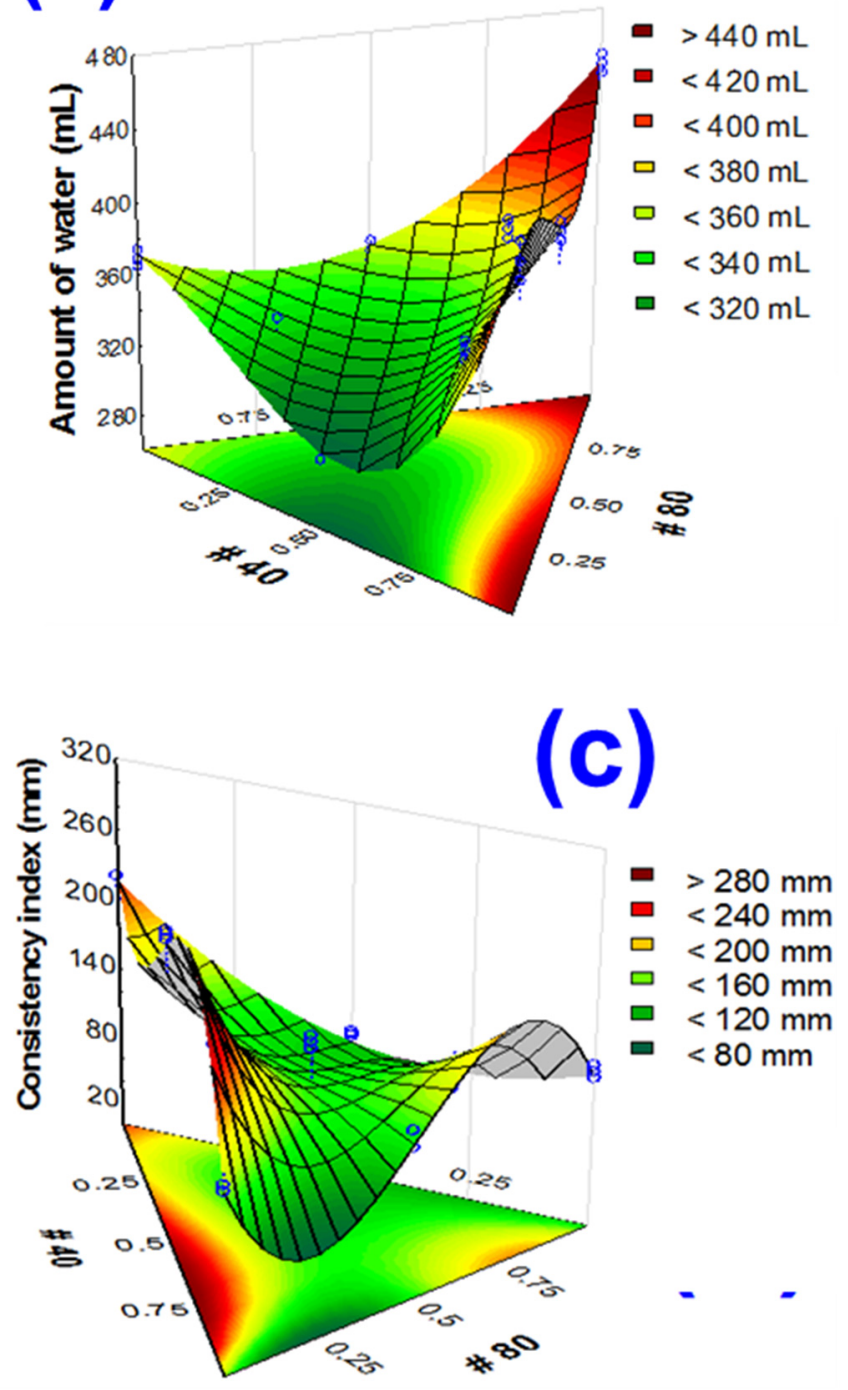
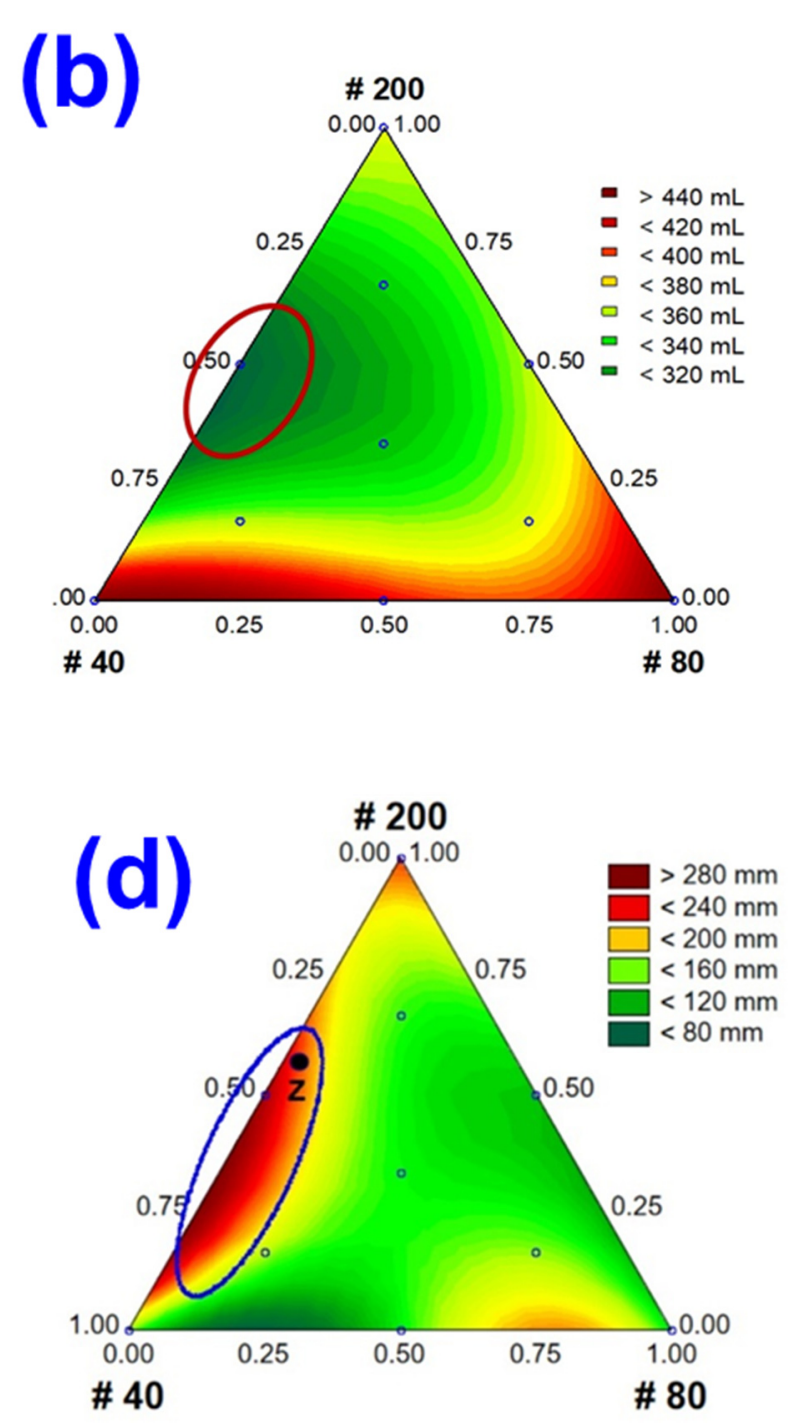

Figure 1. 3D response surface plots and their respective projections onto the composition triangle for the amount of water $(\mathbf{a}, \mathbf{b})$ and consistency index $(\mathbf{c}, \mathbf{d})$.

\subsection{Curing Temperature and Alkaline Activators Concentration Influence on Flexural Strength}

Figure $2 \mathrm{a}-\mathrm{c}$ shows the $3 \mathrm{D}$ response surface plots for the flexural strength versus concentration of alkaline activators $\left(\mathrm{NaOH}, \mathrm{KOH}\right.$, and $\left.\mathrm{Na}_{2} \mathrm{SiO}_{3}\right)$ and curing temperatures. The curing conditions $3 \mathrm{~d}, 5 \mathrm{~d}$, and $4 \mathrm{~d}^{\mathrm{E}}+1 \mathrm{~d}$ were evaluated for $\mathrm{NaOH}, \mathrm{KOH}$ while for the $\mathrm{Na}_{2} \mathrm{SiO}_{3}$, only the $5 \mathrm{~d}$ was performed due to the difficulties in demolding the samples the other experimental conditions. For all conditions, the 3D response surface plot was obtained from the quadratic model ( $95 \%$ confidence). The coefficients of determination $\left(R^{2}\right)$ obtained for curing conditions $3 \mathrm{~d}, 5 \mathrm{~d}$, and $4 \mathrm{~d}^{\mathrm{E}}+1 \mathrm{~d}$ were $73.71 \%, 90.23 \%$, and $92.20 \%$ for the samples activated with $\mathrm{NaOH}$ and $62.54 \%, 90.31 \%$, and $70.33 \%$ for the activation with $\mathrm{KOH}$. Finally, for the $\mathrm{Na}_{2} \mathrm{SiO}_{3}$ activator, $\mathrm{R}^{2}$ was $86.92 \%$ ( $5 \mathrm{~d}$ cure).

The highest FS values were observed at high cure temperatures and $\mathrm{NaOH}$ concentrations (Figure 2a). At intermediate temperatures $\left(\sim 50{ }^{\circ} \mathrm{C}\right)$, the $\mathrm{NaOH}$ activator did not significantly influence FS values in $3 \mathrm{~d}$ and $5 \mathrm{~d}$ cures. However, for the $4 \mathrm{~d}^{\mathrm{E}}+1 \mathrm{~d}$ cures, the FS values increase with $\mathrm{NaOH}$ concentration. In general, in the $\mathrm{NaOH}$-activated samples, FS values ranged from 0 to $2 \mathrm{MPa}$ for $3 \mathrm{~d}, 0$ to $3 \mathrm{MPa}$ for $5 \mathrm{~d}$, and 0 to $2.5 \mathrm{MPa}$ for $4 \mathrm{~d}^{\mathrm{E}}+1 \mathrm{~d}$.

The $\mathrm{KOH}$-activated samples (Figure $2 \mathrm{~b}$ ) show similar behavior as those activated with $\mathrm{NaOH}$ (Figure 2a); i.e., high FS values occur at higher cure temperatures and alkaline 
activator concentrations. However, at $3 \mathrm{~d}$ cure condition, high FS values were obtained at low $\mathrm{KOH}$ concentrations and high cure temperatures. For the $\mathrm{Na}_{2} \mathrm{SiO}_{3}$-activated samples (Figure 2c), the highest FS were obtained for intermediate values of cure temperatures $\left(\sim 50{ }^{\circ} \mathrm{C}\right)$ and activator concentration $(\sim 30 \mathrm{~g} / 100 \mathrm{~g})$. Under these experimental conditions, sodium silicate dissolves silica, which reacts with $\mathrm{Al}^{3+}$ ions, forming aluminosilicate oligomers that unite, promoting the system gelation. It is known that the increase in gel volume favors the increase in mechanical strength [39]. Still for $\mathrm{Na}_{2} \mathrm{SiO}_{3}$, low FS values were observed for higher $\mathrm{Na}_{2} \mathrm{SiO}_{3}$ concentrations. It is believed that high $\mathrm{Na}_{2} \mathrm{SiO}_{3}$ concentrations negatively affect the synthesis kinetics, delaying the $\mathrm{Si}$ dissolution. As a consequence, the hardening of the system will occur when the gel only forms small agglomerates, which compromise the material's mechanical strength [40].

(a)

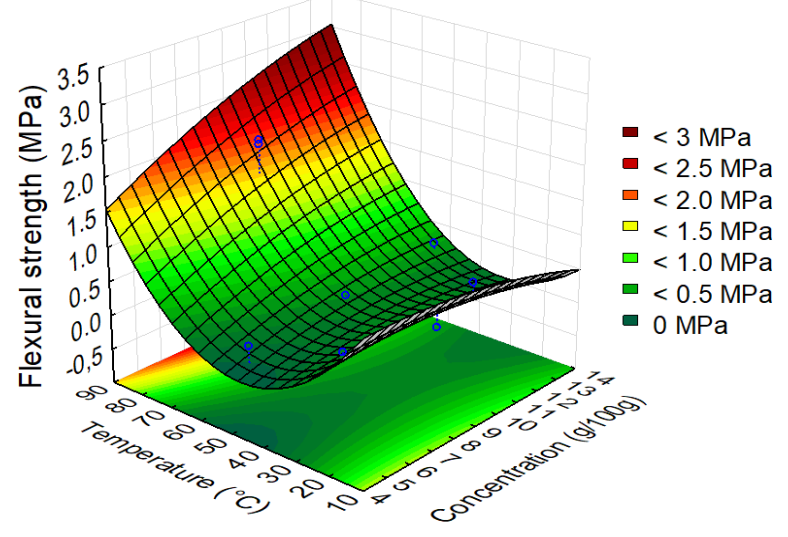

$3 d$

\section{$\mathrm{NaOH}$}

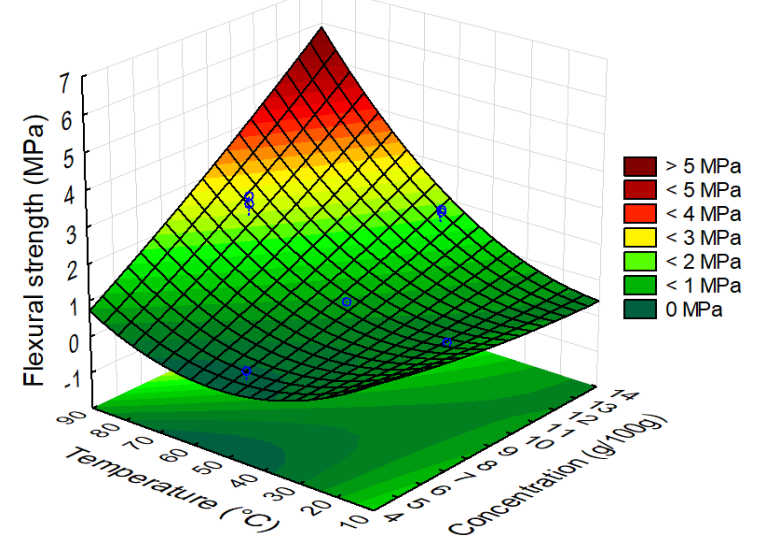

$5 d$

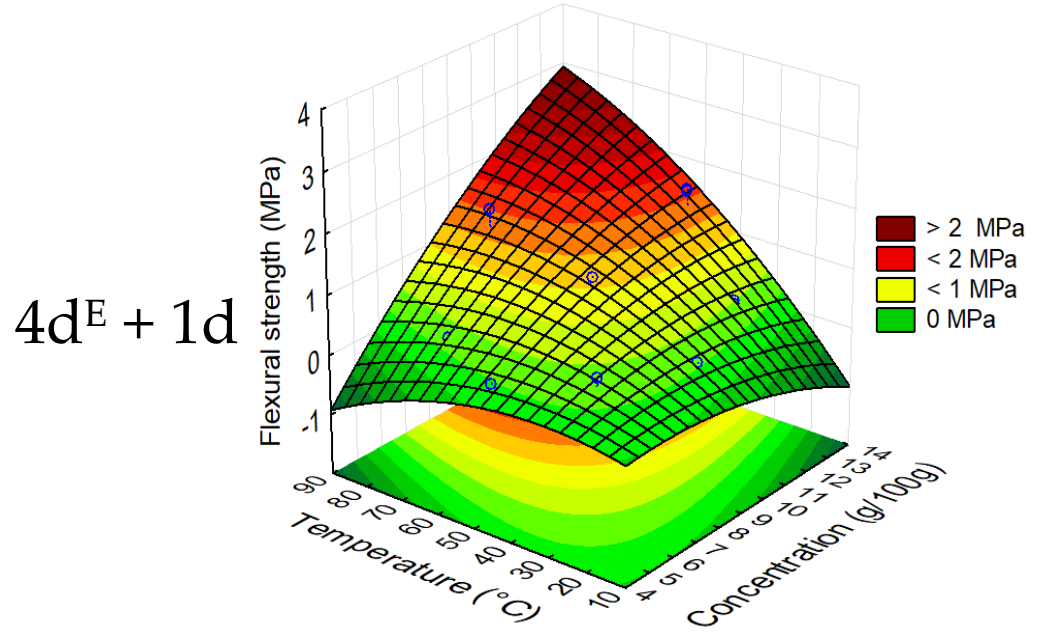

Figure 2. Cont. 
(b)

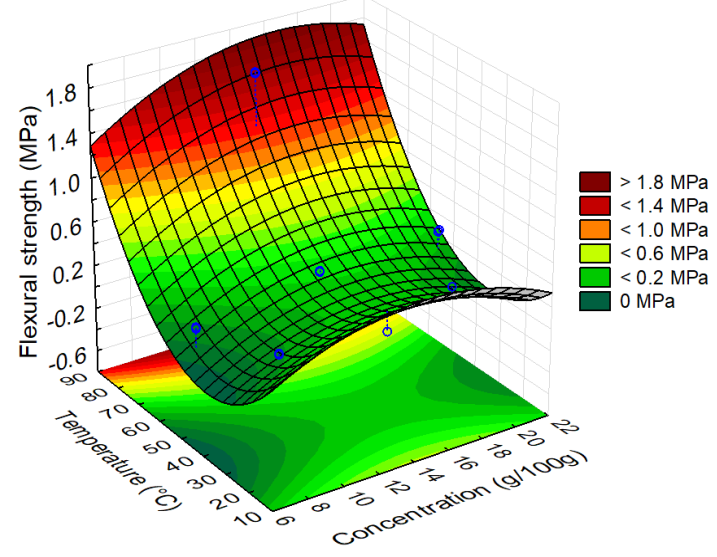

$3 d$

\section{$\mathrm{KOH}$}

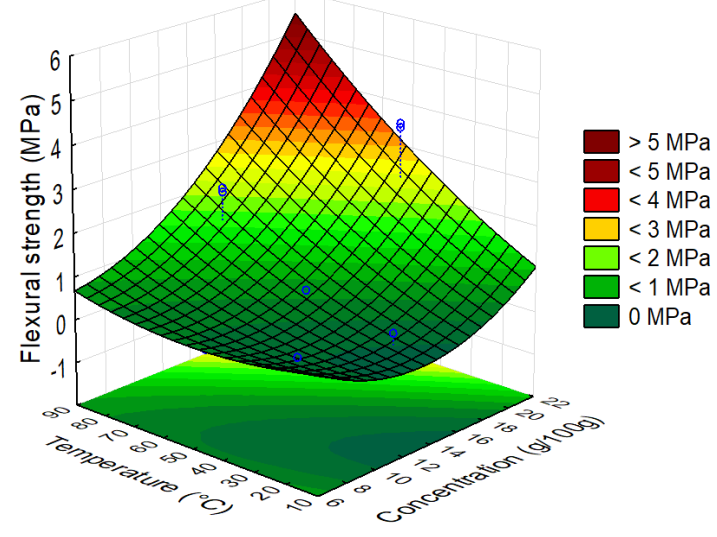

$5 d$

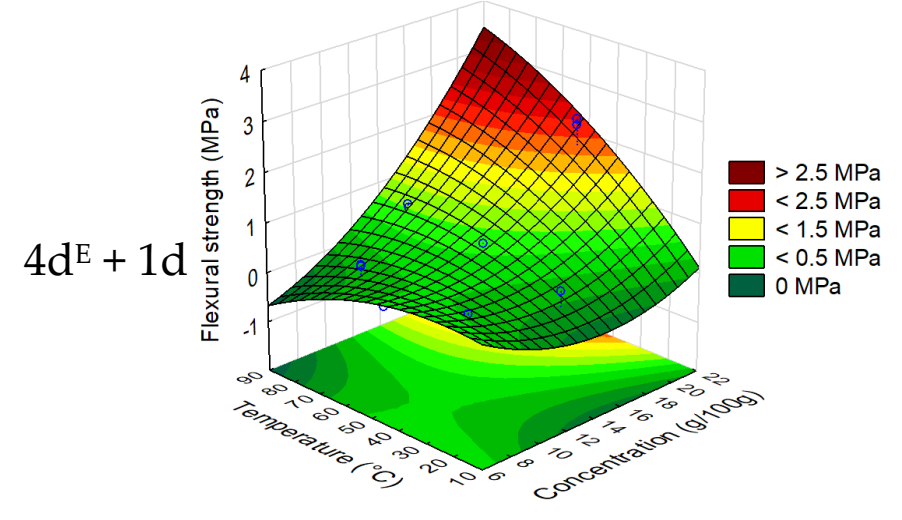

(c)

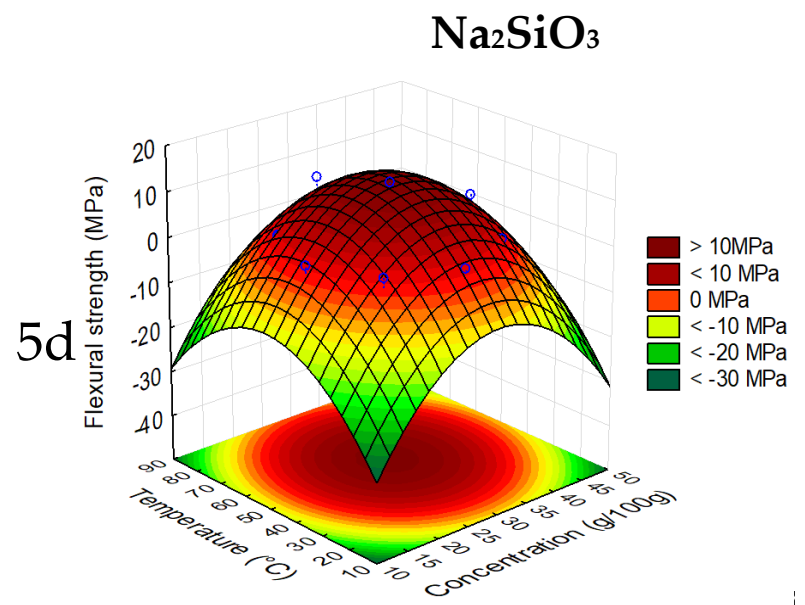

Figure 2. 3D response surface plots obtained from the experimental design of the activators and their cure times. $\mathrm{NaOH}(\mathbf{a})$, $\mathrm{KOH}(\mathbf{b})$ e $\mathrm{Na}_{2} \mathrm{SiO}_{3}$ (c).

According to the 3D response surface plots shown in Figure 2a-c, RNa, RK, and RNaS samples were chosen for the next experiments. The experimental conditions of these samples are summarized in Table 3 . The $5 \mathrm{~d}$ cure was chosen due to their better reproducibility for all studied activators $\left(\mathrm{NaOH}, \mathrm{KOH}\right.$, and $\left.\mathrm{Na}_{2} \mathrm{SiO}_{3}\right)$; since the $\mathrm{Na}_{2} \mathrm{SiO}_{3}$-activated samples subjected to $3 \mathrm{~d}$ and $4 \mathrm{~d}^{\mathrm{E}}+1 \mathrm{~d}$ cures presented difficulties for demolding. In general, the $\mathrm{NaOH}-$ and $\mathrm{KOH}$-activated samples exhibited lower FS values than those activated with $\mathrm{Na}_{2} \mathrm{SiO}_{3}$. Such behavior may be related to large $\mathrm{Si}$ ions contents available in the early stages of geopolymer reactions, which accelerate their kinetics. Indeed, some research [41,42] 
found that activation solution contained $\mathrm{Na}_{2} \mathrm{SiO}_{3}$ which favored the geopolymer reactions, hence improving the mechanical properties.

Table 3. Curing conditions of the $\mathrm{RNa}, \mathrm{RK}$, and $\mathrm{RNaS}$ samples and their predicted flexural strength values.

\begin{tabular}{ccccccc}
\hline & \multicolumn{3}{c}{ Processing Conditions } & \multicolumn{3}{c}{ Cure Type } \\
\cline { 2 - 7 } Samples & \multirow{2}{*}{ Activator } & ${ }^{\mathbf{1}} \mathbf{C}, \mathbf{g} / \mathbf{1 0 0} \mathbf{g}$ & $\mathbf{T},{ }^{\circ} \mathbf{C}$ & $\mathbf{3 d}$ & $\mathbf{5 d}$ & $\mathbf{4 d}^{\mathrm{E}}+\mathbf{1 d}$ \\
\cline { 5 - 7 } & & & & & FS Value $^{\mathbf{2}}$ \\
\hline $\mathrm{RNa}$ & $\mathrm{NaOH}$ & 11.08 & 75 & $1.03-1.88$ & $2.33-3.18$ & $1.64-2.16$ \\
$\mathrm{RK}$ & $\mathrm{KOH}$ & 17.13 & 75 & $0.66-1.52$ & $1.44-3.22$ & $1.10-1.96$ \\
$\mathrm{RNaS}$ & $\mathrm{Na}_{2} \mathrm{SiO}_{3}$ & 33.04 & 55 & - & $10.41-14.96$ & - \\
\hline
\end{tabular}

${ }^{1}$ Concentration; ${ }^{2}$ predictive FS values acquired from Figure $2 \mathrm{a}-\mathrm{c}$.

\subsection{Characterization of the Compositions}

Table 4 and Figure 3a,b show the chemical composition and mineralogical phases analysis of red ceramic residue (RCR) and the alkaline-activated samples ( $R N a, R K$, and $\mathrm{RNaS}$ ). As discussed earlier, all samples were cured under $5 \mathrm{~d}$ conditions. The $\mathrm{SiO}_{2}$ and $\mathrm{Al}_{2} \mathrm{O}_{3}$ were the main oxides detected (44-51 wt $\%$ of $\mathrm{SiO}_{2}$ and $20-26 \mathrm{wt} \%$ of $\mathrm{Al}_{2} \mathrm{O}_{3}$ ). Higher $\mathrm{SiO}_{2}$ and $\mathrm{Al}_{2} \mathrm{O}_{3}$ contents $\left(\mathrm{SiO}_{2}+\mathrm{Al}_{2} \mathrm{O}_{3}=77.3 \mathrm{wt} \%\right)$ in red ceramic residues favored the development of the materials with good mechanical resistance through the process of geopolimerization $[43,44]$. As expected, the $\mathrm{Na}_{2} \mathrm{O}$ and $\mathrm{K}_{2} \mathrm{O}$ contents varied according to the alkaline activator type used. In general, the mineralogical phases of all activated samples (Figure $3 b$ ) were the same as those identified in the ceramic residues (Figure 3a), mica $\left(\mathrm{KMg}_{3}\left(\mathrm{Si}_{3} \mathrm{Al}\right) \mathrm{O}_{10}(\mathrm{OH})_{2}\right.$, JCPDS 83-1808), magnesium silica-aluminate, calcium and sodium (JCPDS 23-1405), feldspar ( $\mathrm{KSi}_{3} \mathrm{AlO}_{3}$, JCPDS 84-0710), quartz ( $\mathrm{SiO}_{2}$, JCPDS 46-1045), and iron oxide $\left(\mathrm{Fe}_{2} \mathrm{O}_{3}\right.$, JCPDS 04-0755).

Table 4. The chemical composition of the red ceramic residue (RCR) and of activated samples (RNa, $\mathrm{RK}$, and $\mathrm{RNaS}$ ).

\begin{tabular}{cccccccccc}
\hline \multirow{2}{*}{ Samples } & \multicolumn{10}{c}{ Oxides (wt\%) } \\
\cline { 2 - 11 } & $\mathbf{S i O}_{\mathbf{2}}$ & $\mathbf{A l}_{\mathbf{2}} \mathbf{O}_{\mathbf{3}}$ & $\mathbf{F e}_{\mathbf{2}} \mathbf{O}_{\mathbf{3}}$ & $\mathbf{N a}_{\mathbf{2}} \mathbf{O}$ & $\mathbf{K}_{\mathbf{2}} \mathbf{O}$ & $\mathbf{M g O}$ & $\mathbf{C a O}$ & $\mathbf{T i O}_{\mathbf{2}}$ & Other \\
\hline $\mathrm{RCR}$ & 51.2 & 26.1 & 9.7 & 1.0 & 3.8 & 3.2 & 1.7 & 1.0 & 1.0 \\
$\mathrm{RNa}$ & 46.4 & 23.2 & 10.0 & 11.5 & 3.7 & 1.8 & 1.7 & 1.0 & 0.7 \\
$\mathrm{RK}$ & 44.3 & 21.9 & 10.3 & - & 18.1 & 2.1 & 1.8 & 1.2 & 0.3 \\
$\mathrm{RNaS}$ & 48.5 & 24.7 & 10.9 & 5.6 & 3.9 & 2.5 & 1.9 & 1.1 & 0.9 \\
\hline
\end{tabular}

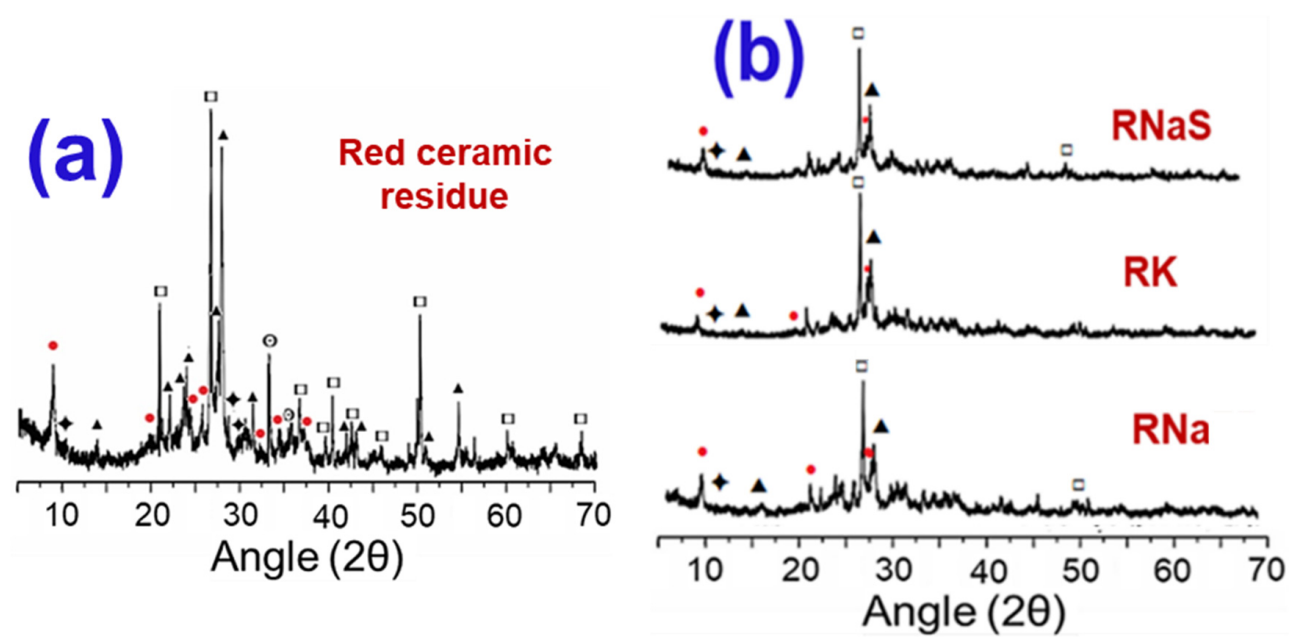

Figure 3. X-ray diffraction pattern measured from of the red ceramic residues (a) and the activated samples (RNa, RK, and $\mathrm{RNaS})(\mathbf{b})(\bullet$ mica, $\downarrow$ magnesium silica-aluminate, $\boldsymbol{\Delta}$ feldspar, $\square$ quartz, $\odot$ iron oxide). 


\subsection{Durability of Activated Samples}

Figure 4 shows the FS results of $\mathrm{RNa}$, RK, and RNaS samples after natural aging (Figure $4 a$ ), accelerated aging by simulated rain (Figure $4 b$ ), exposure to salt spray (Figure 4c), and exposure to hydrochloric and sulfuric acids (Figure $4 \mathrm{~d}, \mathrm{e}$ ). For the $\mathrm{Na}_{2} \mathrm{SiO}_{3}$ activated samples (Figure 4a), was observed the trend of FS values increase around 60 days of exposure and then decrease up to 90 days. For $\mathrm{NaOH}$-activated samples, it was observed that the FS values increased with the exposure time. In the case of $\mathrm{KOH}$, due to the samples being practically deteriorated (Figure $5 \mathrm{a}, \mathrm{b}$ ), it was impossible to measure the FS values at 90 days. Such degradation behavior is related to the sub-efflorescence phenomenon (Figure $5 \mathrm{~b}$ ). In this phenomenon, under adequate humidity, unreacted $\mathrm{K}^{+}$ions leached toward the sample surface and depositing themselves in the salt form of salt.
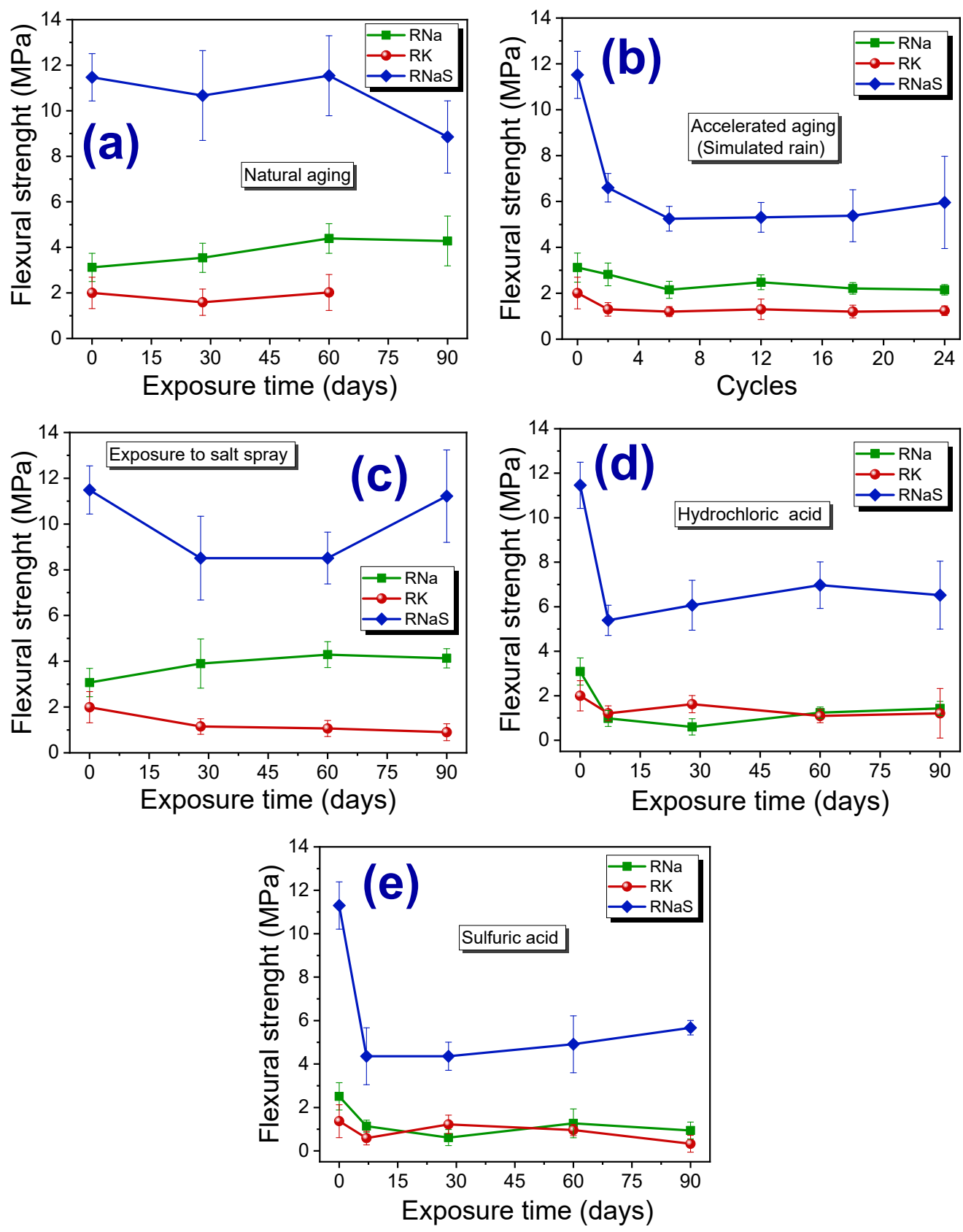

Figure 4. Flexural strength of the $\mathrm{NaOH}-, \mathrm{KOH}_{-}$, and $\mathrm{Na}_{2} \mathrm{SiO}_{3}$-activated samples subjected to natural aging (a), accelerated aging by simulated rain (b), exposure to salt spray (c), to hydrochloric acid (d), and sulfuric acid (e). 


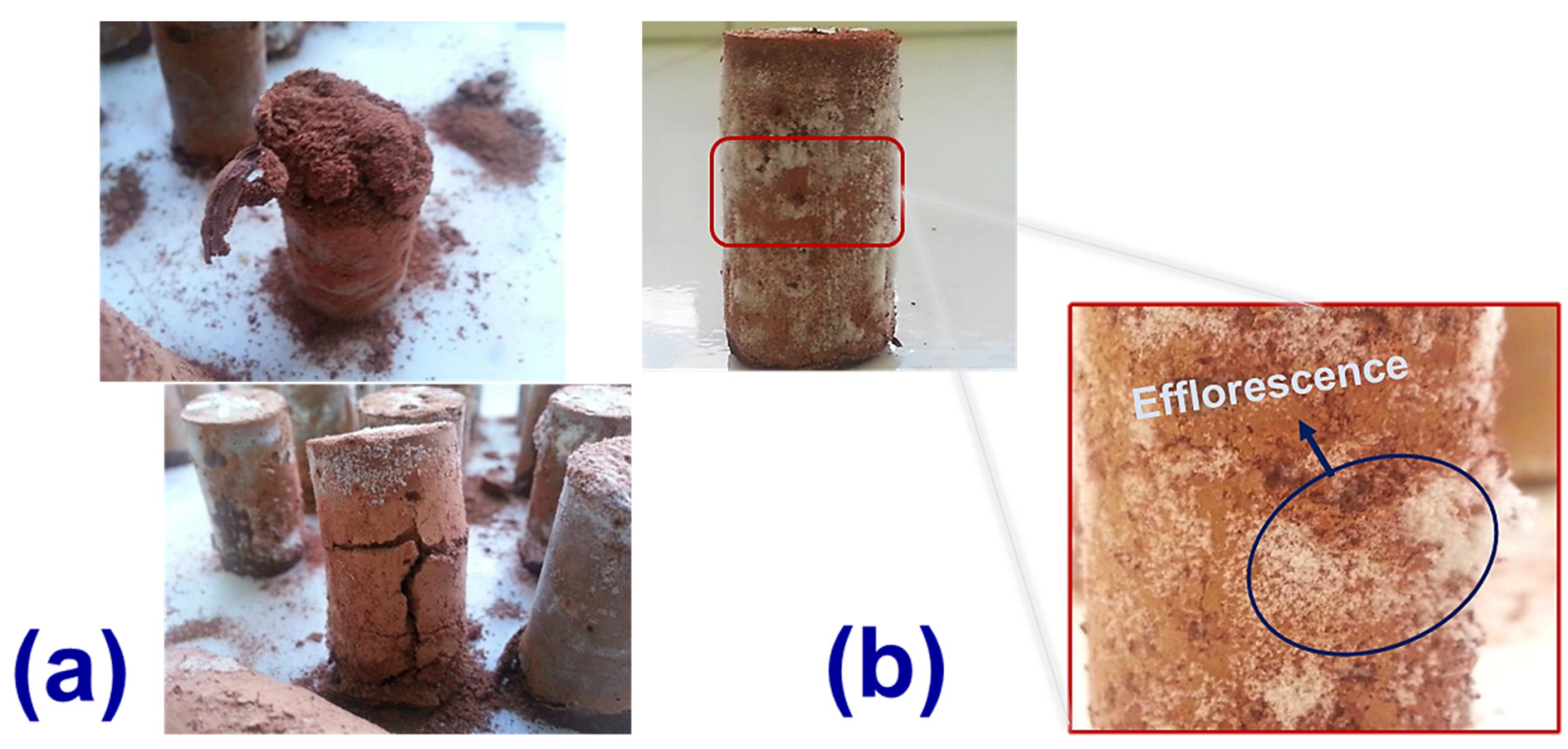

Figure 5. Evolution of the deterioration process of $\mathrm{KOH}$-activated samples after 60 days of natural aging (a), and efflorescence phenomenon exhibited by the RK sample (b).

For samples subjected to accelerated aging by simulated rain (Figure $4 \mathrm{~b}$ ), from $0^{\circ}$ to $2^{\circ}$ cycles, a significant decrease in $\mathrm{FS}$ values was observed only in the $\mathrm{Na}_{2} \mathrm{SiO}_{3}$-activated sample. Such behavior must be related to the leaching of soluble silica [45]. From the $2^{\circ}$ to $6^{\circ}$ cycles, the FS values decreased for all samples, regardless of the activator used, obtaining a subtle increase in the $12^{\circ}$ cycle. This behavior may be related to the initial leaching of soluble particles present in the material structure. However, such behavior stabilizes with the continuation of the wetting and drying cycles, either by decreasing the ions leaching rate or increasing geopolymerization over cycles. From the $12^{\circ}$ cycle onwards, $\mathrm{NaOH}$ and $\mathrm{KOH}$-activated samples showed similar behaviors, indicating a slight decrease in resistance for the $18^{\circ}$ and $24^{\circ}$ cycles.

Figure 4c shows the FS values of alkali-activated samples that were exposed to salt spray for 28, 60, and 90 days. The mechanical resistance measured from $\mathrm{NaOH}$ and $\mathrm{KOH}$ samples did not undergo significant changes during the experiment. Unlike what was observed in natural aging, the sub-efflorescence phenomenon was not observed in the $\mathrm{KOH}$ sample; thus, $\mathrm{FS}$ values were measured at 90 days. For $\mathrm{Na}_{2} \mathrm{SiO}_{3}$-activated sample, from 60 to 90 days, there is a considerable increase in FS values. Probably this behavior is related to the continuation of the geopolymerization reactions or due to variations in the environment humidity, which favored the dissolution reactions and condensation. For the samples exposed (immersed) in $\mathrm{HCl}$ and $\mathrm{H}_{2} \mathrm{SO}_{4}$ solutions (Figure $4 \mathrm{~d}$,e), it was noted that the $\mathrm{NaOH}$ - and $\mathrm{KOH}$-activated samples presented similar durability behavior, and there are no significant variations in $\mathrm{FS}$ values for these samples. For $\mathrm{Na}_{2} \mathrm{SiO}_{3}$-activated samples, there is a considerable decrease in resistance in the period from 0 to 7 days. After 7 days, the resistance tends to stabilize with the time of exposure.

Figure 6 compares the FS values measured from $\mathrm{RNa}, \mathrm{RK}$, and $\mathrm{RNaS}$ samples with natural aging with different geopolymers found in the literature. The following materials were collected from the literature: commercial metakaolin (GM) activated with sodium silicate/sodium hydroxide solution [35], ceramic residue (GPM 0.6)-activated alkaline activated with sodium silicate/sodium hydroxide solution [46], chamotte residues molded and pressed (CM and $\mathrm{CP}$, respectively) alkali activated with potassium hydroxide/sodium silicate solution [31], Metakaolin HP Ultra molded and pressed (MM and MP, respectively) alkali activated with hydroxide/sodium silicate solution [31], fly ash with a proportion of $15 \%$ granulated blast furnace slag (AA3) alkali activated with sodium silicate solution [47], blast furnace slag and fly ash (50FA1.00) alkali active with $\mathrm{Na}_{2} \mathrm{SiO}_{3} / \mathrm{NaOH}$ solution [48], 
geopolymeric concrete prepared using a Class $\mathrm{F}$ fly ash (A40 S00), and alkali activated with $114.3 \mathrm{~kg} / \mathrm{m}^{3} \mathrm{Na}_{2} \mathrm{SiO}_{3}$ and $45.7 \mathrm{~kg} / \mathrm{m}^{3} \mathrm{NaOH}$ solution and $100 \mathrm{~kg} / \mathrm{m}^{3}$ of $\mathrm{Na}_{2} \mathrm{SiO}_{3}$ and $40 \mathrm{NaOH} \mathrm{kg} / \mathrm{m}^{3}$ solution (A35 S00) [49], fly ash-based mixtures (AF-AS) and ground granulated blast furnace slag (GGBS) alkali activated with sodium hydroxide/sodium silicate solution [50], low-calcium fly ash (GPC) alkali activated with $\left(103 \mathrm{~kg} / \mathrm{m}^{3}\right)$ sodium hydroxide $/\left(41 \mathrm{~kg} / \mathrm{m}^{3}\right)$ sodium silicate solution [51].

The highest FS values were found for Metakaolin HP Ultra pressed (MP: $30.44 \mathrm{MPa}$ ) and molded (MM: 12.50 MPa) residues [31]. In this case, the proper cure temperature was also investigated, and it was observed that the aluminosilicate dissolution reactions reached a maximum at $60^{\circ} \mathrm{C}$. RNaS sample, in this work, presented values around $11.5 \mathrm{MPa}$, in cures of 0 and 60 days, which were superior to other materials. RK and RNa samples in this work showed FS values ranging between 2 and $4.2 \mathrm{MPa}$, being lower than other strengths shown in Figure 6, except for the AA3 and GGBS samples. Sample AA3 was activated with $8 \%$ sodium silicate content, and the authors observed that for lower levels, the FS values decreased. According to the authors, the FS value for the AA3 sample (2.1 MPa) was satisfactory. GGBS sample showed the lowest FS result compared to other materials analyzed. This behavior occurs due to the fragile structure matrix produced from GGBS.

In general, it is possible to observe the increase of FS with the curing time; this behavior is expected because, for them to occur as geopolymerization and compaction reactions of the specimens in a satisfactory way, an adequate curing time is necessary [31]. However, for the samples in this work, the highest resistance was observed in 60 days of exposure for $\mathrm{RNa}$ and $\mathrm{RNaS}$ and 28 days of exposure to RK. Probably the geopolymerization reactions were consolidated at these ages.

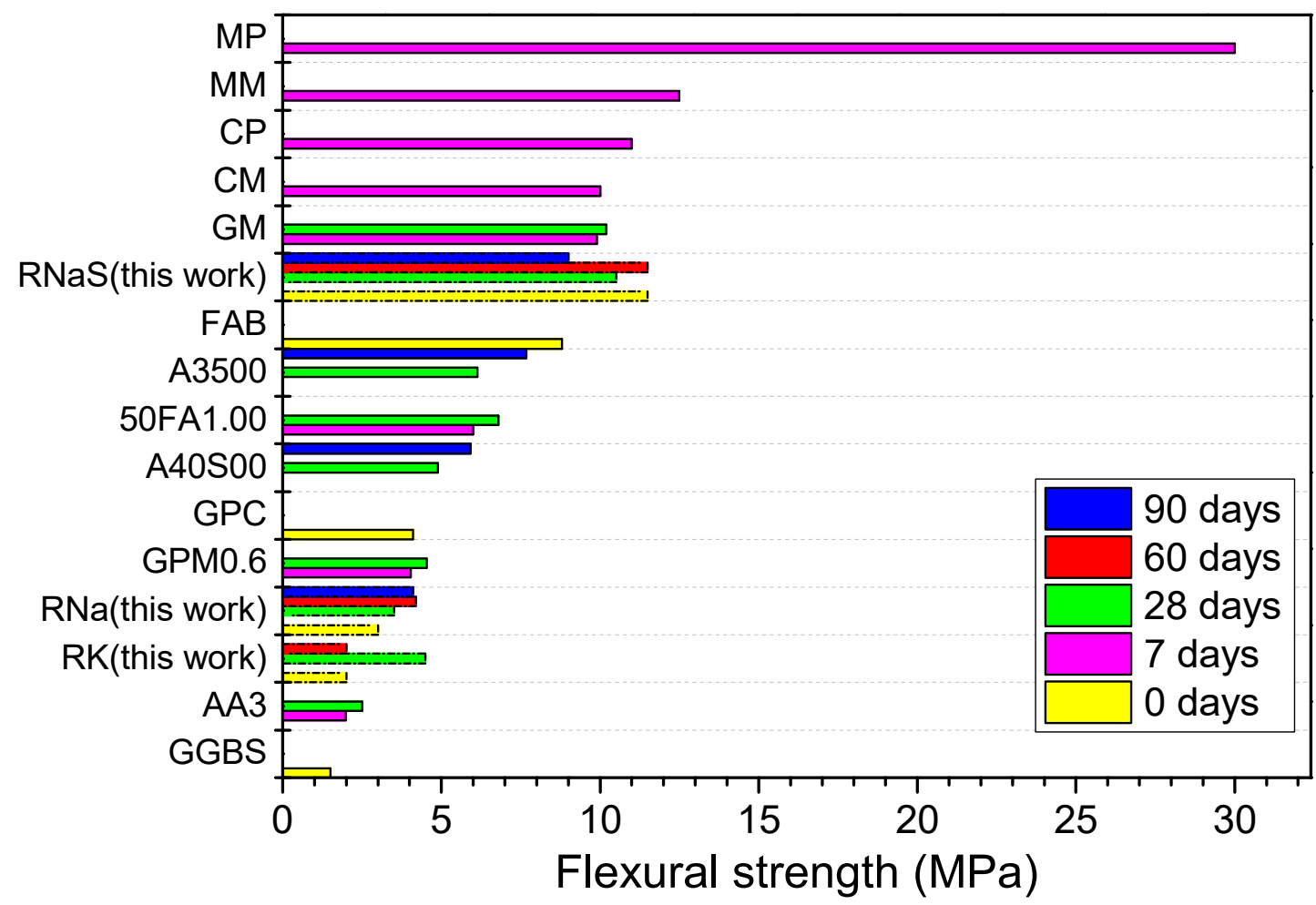

Figure 6. Comparison of the flexural strength of the red ceramic residues activated with $\mathrm{NaOH}(\mathrm{RNa}), \mathrm{KOH}(\mathrm{RK})$, and $\mathrm{Na}_{2} \mathrm{SiO}_{3}(\mathrm{RNaS})$ evaluated in this study with different geopolymers found in the literature.

\section{Conclusions}

The red ceramic residues showed potential to be used in the alkaline activation technique to obtain geopolymers. Curing conditions (temperature and time) and types and concentrations of the alkaline activator influenced the samples' mechanical strength and 
durability. The samples activated with $\mathrm{NaOH}$ and $\mathrm{KOH}$ exhibited less mechanical behavior than the samples activated with $\mathrm{Na}_{2} \mathrm{SiO}_{3}$. For $\mathrm{NaOH}$ and $\mathrm{KOH}$ activators, the highest flexural strength values were obtained with the combination of elevated temperatures and higher concentrations of the activator. In the case of the $\mathrm{Na}_{2} \mathrm{SiO}_{3}$ activator, to obtain higher mechanical resistance values, a balance between the activator concentration and the curing temperature is necessary. In the durability studies, there was a decrease in mechanical resistance with an increase in exposure cycles to aggressive conditions, and for natural aging, mechanical resistance increased over time.

Author Contributions: Methodology, software, data curation, and formal analysis, I.M.T.B., F.P.d.C. and J.V.F. Conceptualization, supervision, funding acquisition, and project administration, G.d.A.N. and R.R.M. Formal analysis, writing-review and editing, A.M.R. All authors have read and agreed to the published version of the manuscript.

Funding: This research was funded by Coordenação de Aperfeiçoamento de Pessoal de Nivel Superior (CAPES), grant number 88887.597478/2021-00; and by Conselho Nacional de Desenvolvimento Científico e Tecnológico (CNPq), grant number 140211/2021-7.

Institutional Review Board Statement: Not applicable.

Informed Consent Statement: Not applicable.

Acknowledgments: The authors would like to thank the support provided by the Laboratório de Tecnologia dos Materiais, where it was possible to carry out the experiments of this work.

Conflicts of Interest: The authors declare no conflict of interest.

\section{References}

1. da Silva, A.C.; Méxas, M.P.; Quelhas, O.L.G. Restrictive factors in implementation of clean technologies in red ceramic industries. J. Clean. Prod. 2017, 168, 441-451. [CrossRef]

2. Azevedo, A.R.G.; França, B.R.; Alexandre, J.; Marvila, M.T.; Zanelato, E.B.; Xavier, G.C. Influence of sintering temperature of a ceramic substrate in mortar adhesion for civil construction. J. Build. Eng. 2018, 19, 342-348. [CrossRef]

3. Nandi, V.S.; Raupp-Pereira, F.; Montedo, O.R.K.; Oliveira, A.P.N. The use of ceramic sludge and recycled glass to obtain engobes for manufacturing ceramic tiles. J. Clean. Prod. 2015, 86, 461-470. [CrossRef]

4. Almeida, E.P.; Carreiro, M.E.A.; Rodrigues, A.M.; Ferreira, H.S.; Santana, L.N.L.; Menezes, R.R.; Neves, G.A. A new eco-friendly mass formulation based on industrial mining residues for the manufacture of ceramic tiles. Ceram. Int. 2020, 47, 11340-11348. [CrossRef]

5. de Figueirêdo, J.M.R.; da Costa, F.P.; Fernandes, J.V.; Rodrigues, A.M.; de Araújo Neves, G.; Menezes, R.R.; de Lima Santana, L.N. Development of Scheelite Tailings-Based Ceramic Formulations with the Potential to Manufacture Porcelain Tiles, Semi-Stoneware and Stoneware. Materials 2020, 13, 5122. [CrossRef]

6. Fernandes, J.V.; Guedes, D.G.; da Costa, F.P.; Rodrigues, A.M.; Neves, G.d.A.; Menezes, R.R.; Santana, L.N.d.L. Sustainable Ceramic Materials Manufactured from Ceramic Formulations Containing Quartzite and Scheelite Tailings. Sustainability 2020, 12, 9417. [CrossRef]

7. Siddique, S.; Chaudhary, S.; Shrivastava, S.; Gupta, T. Sustainable utilisation of ceramic waste in concrete: Exposure to adverse conditions. J. Clean. Prod. 2018, 210, 246-255. [CrossRef]

8. Awoyera, P.O.; Ndambuki, J.M.; Akinmusuru, J.O.; Omole, D.O. Characterization of ceramic waste aggregate concrete. HBRC J. 2018, 14, 282-287. [CrossRef]

9. Nayana, A.M.; Rakesh, P. Strength and durability study on cement mortar with ceramic waste and micro-silica. Mater. Today: Proc. 2018, 5, 24780-24791. [CrossRef]

10. Vieira, C.M.F.; Monteiro, S.N. Effect of grog addition on the properties and microstructure of a red ceramic body for brick production. Constr. Build. Mater. 2007, 21, 1754-1759. [CrossRef]

11. Luhar, I.; Luhar, S.; Abdullah, M.M.A.B.; Nabiałek, M.; Sandu, A.V.; Szmidla, J.; Jurczyńska, A.; Razak, R.A.; Aziz, I.H.A.; Jamil, N.H.; et al. Assessment of the Suitability of Ceramic Waste in Geopolymer Composites: An Appraisal. Materials 2021, 14, 3279. [CrossRef]

12. Provis, J.; Bernal, S.A. Geopolymers and Related Alkali-Activated Materials. Annu. Rev. Mater. Res. 2014, 44, 299-327. [CrossRef]

13. Galvão Souza Azevedo, A.; Strecker, K. Kaolin, fly-ash and ceramic waste based alkali-activated materials production by the "one-part" method. Constr. Build. Mater. 2020, 269, 121306. [CrossRef]

14. Ye, N.; Yang, J.; Liang, S.; Hu, Y.; Hu, J.; Xiao, B.; Huang, Q. Synthesis and strength optimization of one-part geopolymer based on red mud. Constr. Build. Mater. 2016, 111,317-325. [CrossRef]

15. Huseien, G.F.; Sam, A.R.M.; Shah, K.W.; Asaad, M.A.; Tahir, M.M.; Mirza, J. Properties of ceramic tile waste based alkali-activated mortars incorporating GBFS and fly ash. Constr. Build. Mater. 2019, 214, 355-368. [CrossRef] 
16. Marvila, M.T.; Alexandre, J.; Azevedo, A.R.G.; Zanelato, E.B.; Xavier, G.C.; Monteiro, S.N. Study on the replacement of the hydrated lime by kaolinitic clay in mortars. Adv. Appl. Ceram. 2019, 118, 373-380. [CrossRef]

17. Lahoti, M.; Tan, K.H.; Yang, E.-H. A critical review of geopolymer properties for structural fire-resistance applications. Constr. Build. Mater. 2019, 221, 514-526. [CrossRef]

18. Terrones-Saeta, J.M.; Suárez-Macías, J.; Iglesias-Godino, F.J.; Corpas-Iglesias, F.A. Development of Geopolymers as Substitutes for Traditional Ceramics for Bricks with Chamotte and Biomass Bottom Ash. Materials 2021, 14, 199. [CrossRef] [PubMed]

19. Hajimohammadi, A.; van Deventer, J.S. Characterisation of One-Part Geopolymer Binders Made from Fly Ash. Waste Biomass Valori. 2016, 8, 225-233. [CrossRef]

20. Angulo-Ramirez, D.E.; De Gutiérrez, R.M.; Valencia-Saavedra, W.G.; De Medeiros, M.H.F.; Hoppe-Filho, J. Carbonation of hybrid concrete with high blast furnace slag content and its impact on structural steel corrosion. Mater. Construcción 2019, 69, 182. [CrossRef]

21. Ruiz-Santaquiteria, C.; Fernández-Jimenez, A.; Skibsted, J.; Palomo, A. Clay reactivity: Production of alkali activated cements. Appl. Clay Sci. 2013, 73, 11-16. [CrossRef]

22. Mehta, A.; Siddique, R. An overview of geopolymers derived from industrial by-products. Constr. Build. Mater. 2016, 127, 183-198. [CrossRef]

23. Nie, Q.; Hu, W.; Ai, T.; Huang, B.; Shu, X.; He, Q. Strength properties of geopolymers derived from original and desulfurized red mud cured at ambient temperature. Constr. Build. Mater. 2016, 125, 905-911. [CrossRef]

24. Hajimohammadi, A.; van Deventer, J.S. Solid Reactant-Based Geopolymers from Rice Hull Ash and Sodium Aluminate. Waste Biomass Valori. 2016, 8, 2131-2140. [CrossRef]

25. Arulrajah, A.; Kua, T.A.; Horpibulsuk, S.; Phetchuay, C.; Suksiripattanapong, C.; Du, Y.J. Strength and microstructure evaluation of recycled glass-fly ash geopolymer as low-carbon masonry units. Constr. Build. Mater. 2016, 114, 400-406. [CrossRef]

26. Novais, R.M.; Ascensão, G.; Seabra, M.P.; Labrincha, J.A. Waste glass from end-of-life fluorescent lamps as raw material in geopolymers. Waste Manag. 2016, 52, 245-255. [CrossRef]

27. Mendes, J.P.; Elyseu, F.; Nieves, L.J.J.; Zaccaron, A.; Bernardin, A.M.; Angioletto, E. Synthesis and characterization of geopolymers using clay ceramic waste as source of aluminosilicate. Sustain. Mater. Technol. 2021, 28, e00264. [CrossRef]

28. Robayo-Salazar, R.A.; Rivera, J.F.; de Gutierrez, R.M. Alkali-activated building materials made with recycled construction and demolition wastes. Constr. Build. Mater. 2017, 149, 130-138. [CrossRef]

29. Sarkar, M.; Dana, K. Partial replacement of metakaolin with red ceramic waste in geopolymer. Ceram. Int. 2020, 47, 3473-3483. [CrossRef]

30. Rego, S.R.; Gomes, K.C.; Rosas, M.; Torres, S.M.; de Barros, S. Application of Geopolymeric Adhesives in Ceramic Systems Subjected to Cyclic Temperature Environments. J. Adhes. 2013, 90, 120-133. [CrossRef]

31. Azevedo, A.R.G.; Vieira, C.M.F.; Ferreira, W.M.; Faria, K.C.P.; Pedroti, L.G.; Mendes, B.C. Potential use of ceramic waste as precursor in the geopolymerization reaction for the production of ceramic roof tiles. J. Build. Eng. 2019, 29, 101156. [CrossRef]

32. ASTM. C1437 Standard Test Method for Flow of Hydraulic Cement Mortar; ASTM International: West Conshohocken, PA, USA, 2020.

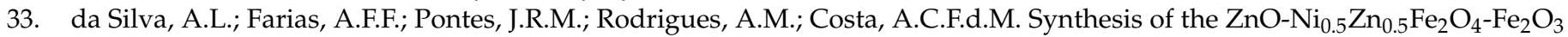
magnetic catalyst in pilot-scale by combustion reaction and its application on the biodiesel production process from oil residual. Arab. J. Chem. 2020, 13, 7665-7679. [CrossRef]

34. Correia, S.L.; Partala, T.; Loch, F.C.; Segadães, A.M. Factorial design used to model the compressive strength of mortars containing recycled rubber. Compos. Struct. 2010, 92, 2047-2051. [CrossRef]

35. Rovnaník, P. Effect of curing temperature on the development of hard structure of metakaolin-based geopolymer. Constr. Build. Mater. 2010, 24, 1176-1183. [CrossRef]

36. Medri, V.; Fabbri, S.; Dedecek, J.; Sobalik, Z.; Tvaruzkova, Z.; Vaccari, A. Role of the morphology and the dehydroxylation of metakaolins on geopolymerization. Appl. Clay Sci. 2010, 50, 538-545. [CrossRef]

37. Al Bakria, A.M.M.; Kamarudin, H.; BinHussain, M.; Nizar, I.K.; Zarina, Y.; Rafiza, A.R. The Effect of Curing Temperature on Physical and Chemical Properties of Geopolymers. Phys. Procedia 2011, 22, 286-291. [CrossRef]

38. Heah, C.Y.; Kamarudin, H.; Mustafa Al Bakri, A.M.; Binhussain, M.; Luqman, M.; Khairul Nizar, I.; Ruzaidi, C.M.; Liew, Y.M. Effect of Curing Profile on Kaolin-based Geopolymers. Phys. Procedia 2011, 22, 305-311. [CrossRef]

39. Weng, L.; Sagoe-Crentsil, K. Dissolution processes, hydrolysis and condensation reactions during geopolymer synthesis: Part I-Low Si / Al ratio systems. J. Mater. Sci. 2007, 42, 2997-3006. [CrossRef]

40. Duxson, P.; Provis, J.L.; Lukey, G.C.; Mallicoat, S.W.; Kriven, W.M.; van Deventer, J.S. Understanding the relationship between geopolymer composition, microstructure and mechanical properties. Colloids Surf. A Physicochem. Eng. Asp. 2005, 269, 47-58. [CrossRef]

41. Granizo, M.L.; Blanco-Varela, M.T.; Martinez-Ramirez, S. Alkali activation of metakaolins: Parameters affecting mechanical, structural and microstructural properties. J. Mater. Sci. 2007, 42, 2934-2943. [CrossRef]

42. Criado, M.; Palomo, A.; Fernández-Jimenez, A.M. Alkali activation of fly ashes. Part 1: Effect of curing conditions on the carbonation of the reaction products. Fuel 2005, 84, 2048-2054. [CrossRef]

43. Singh, J.; Singh, S.P. Geopolymerization of solid waste of non-ferrous metallurgy-A review. J. Environ. Manag. 2019, $251,109571$. [CrossRef] 
44. Narayanan, A.; Shanmugasundaram, P. An Experimental Investigation on Flyash-based Geopolymer Mortar under different curing regime for Thermal Analysis. Energy Build. 2017, 138, 539-545. [CrossRef]

45. Saludung, A.; Azeyanagi, T.; Ogawa, Y.; Kawai, K. Effect of silica fume on efflorescence formation and alkali leaching of alkali-activated slag. J. Clean. Prod. 2021, 315, 128210. [CrossRef]

46. Shoaei, P.; Musaeei, H.R.; Mirlohi, F.; Narimani Zamanabadi, S.; Ameri, F.; Bahrami, N. Waste ceramic powder-based geopolymer mortars: Effect of curing temperature and alkaline solution-to-binder ratio. Constr. Build. Mater. 2019, 227, 116686. [CrossRef]

47. Yousefi Oderji, S.; Chen, B.; Ahmad, M.R.; Shah, S.F.A. Fresh and hardened properties of one-part fly ash-based geopolymer binders cured at room temperature: Effect of slag and alkali activators. J. Clean. Prod. 2019, 225, 1-10. [CrossRef]

48. Çelikten, S.; Sarıdemir, M.; Özgür Deneme, İ. Mechanical and microstructural properties of alkali-activated slag and slag + fly ash mortars exposed to high temperature. Constr. Build. Mater. 2019, 217, 50-61. [CrossRef]

49. Nath, P.; Sarker, P. Flexural strength and elastic modulus of ambient-cured blended low-calcium fly ash geopolymer concrete. Constr. Build. Mater. 2017, 130, 22-31. [CrossRef]

50. Bagheri, A.; Nazari, A.; Sanjayan, J.G. Fibre-reinforced boroaluminosilicate geopolymers: A comparative study. Ceram. Int. 2018, 44, 16599-16605. [CrossRef]

51. Ganesan, N.; Abraham, R.; Deepa Raj, S. Durability characteristics of steel fibre reinforced geopolymer concrete. Constr. Build. Mater. 2015, 93, 471-476. [CrossRef] 